\title{
Accumulation of the angucycline antibiotic rabelomycin after disruption of an oxygenase gene in the jadomycin B biosynthetic gene cluster of Streptomyces venezuelae
}

\author{
Keqian Yang, ${ }^{1}$ Lei Han, ${ }^{1} \dagger$ Stephen W. Ayer ${ }^{2}$ and Leo C. Vining ${ }^{1}$ \\ Author for correspondence: Leo C. Vining. Tel. +1902494 2040. Fax. +19024943736. \\ e-mail: lvining@ac.dal.ca
}

1 Department of Biology, Dalhousie University, Halifax, Nova Scotia, Canada B3H 4J1

2 Institute for Marine Biosciences, National Research Council of Canada, Halifax, Nova Scotia, Canada B3H $3 Z 1$

\begin{abstract}
DNA from a region downstream of and overlapping the polyketide synthase (PKS) gene cluster for jadomycin B biosynthesis in Streptomyces venezuelae was cloned and sequenced. Analysis of the nucleotide sequence located one complete ORF (ORF6), an incomplete one representing the 3 ' region of ORF4 in the PKS cluster, and a second incomplete one (ORF7). The deduced amino acid sequences for ORFs 6 and 7 resemble those of oxygenases. Since a plausible biosynthetic pathway for jadomycin B includes an angular polyketide intermediate that undergoes oxidative ring fission before condensation with an amino acid, we subcloned one of the presumptive oxygenase genes (ORF6) in a segregationally unstable shuttle vector (pHJL400) and disrupted it by inserting the gene for apramycin resistance. Transformation of $S$. venezuelae with the disruption vector and selection for apramycin resistance gave mutants blocked in jadomycin biosynthesis. Southern hybridization confirmed that gene replacement had occurred. Cultures of the mutants accumulated a metabolite identified by comparison with an authentic sample as rabelomycin, a non-nitrogenous polyketide-derived antibiotic originally isolated from Streptomyces olivaceus.
\end{abstract}

Keywords: Streptomyces venequelae, angucycline, gene disruption, jadomycin B, polyketide antibiotic

\section{INTRODUCTION}

Streptomyces venezuelae ISP5230 produces a group of novel angucycline antibiotics when cultures grown under nutrient limitation in a medium containing poorly assimilated sources of carbon and nitrogen are exposed to additional stress, such as heat shock, phage infection or exposure to toxic concentrations of ethanol (Doull et al., 1993, 1994). Jadomycin B, the main component produced during growth in an isoleucine-containing medium, has an isoleucine moiety fused into the cyclic structure and is glycosylated (Fig. 1; Ayer et al., 1991). Under less severe stress conditions, S. venezuelae ISP5230 produces chloramphenicol (Doull et al., 1985).

† Present address: Department of Pharmaceutical Sciences, School of Pharmacy, University of Maryland at Baltimore, 20 North Pine Street, Baltimore, MD 21201, USA.

Abbreviation: PKS, polyketide synthase.

The GenBank accession number for the nucleotide sequence reported in this paper is U28382.
Although the biosynthesis of jadomycin B has not been examined in detail, the inference from inspection of the chemical structure that it is derived from a polyketide intermediate was supported by specific incorporation into the structure of isotopically labelled acetate (S. Ayer,<smiles></smiles>

Fig. 1. Molecular structure of jadomycin B 
unpublished data). Cloning and sequence analysis of a fragment of $S$. venezuelae ISP5230 genomic DNA that hybridizes with act genes from Streptomyces coelicolor A3(2) established the presence of a polyketide synthase (PKS) gene cluster in S. venezuelae. Selective loss of jadomycin B production when a plasmid containing part of the cloned sequence integrated into the chromosome indicated that the PKS genes are associated with jadomycin biosynthesis (Han et al., 1994).

In this paper, we present evidence that a region of the $S$. venezuelae ISP 5230 chromosome immediately downstream of the PKS gene cluster encodes an oxygenase involved in opening ring B of an angucycline (Rohr \& Thiericke, 1992) likely to be a biosynthetic intermediate. Subsequent insertion of an isoleucine molecule at this site would account for the formation of jadomycins.

\section{METHODS}

Bacterial strains, plasmids and culture conditions. Sources and characteristics of the bacteria and plasmids used are listed in Table 1. Cultures of Streptomyces venequelae and Escherichia coli were grown as described previously (Han et al., 1994). The conditions used for jadomycin B production were as described by Doull et al. (1994). For selective growth of $S$. venezuelae mutant strains, apramycin was added at concentrations of $50 \mu \mathrm{g}$ $\mathrm{ml}^{-1}$ to agar media and $10 \mu \mathrm{g} \mathrm{ml}^{-1}$ to liquid media.

DNA manipulation and transformation. Plasmid DNA was isolated from $E$. coli by the alkaline lysis method of Kieser (1984). Genomic DNA was isolated as described by Hopwood et al. (1985). DNA ligase and restriction enzymes were used according to manufacturers' instructions. Competent cells of $E$. coli were prepared and transformed by standard methods (Sambrook et al., 1989); protoplasts of $S$. venezuelae were prepared and transformed by modifying the methods of Hopwood et al. (1985) as follows: MYME medium, containing $10 \cdot 3 \%(\mathrm{w} / \mathrm{v})$ sucrose, $1 \%(\mathrm{w} / \mathrm{v})$ maltose, $0.5 \%(\mathrm{w} / \mathrm{v})$ peptone, $0.3 \%(\mathrm{w} / \mathrm{v})$ yeast extract, $0.3 \%(\mathrm{w} / \mathrm{v})$ malt extract, $5 \mathrm{mM}$ $\mathrm{MgCl}_{2}$ and $1 \%(\mathrm{w} / \mathrm{v}$ ) glycine, was inoculated with $S$. venezuelae ISP5230 spores and incubated for $48 \mathrm{~h}$ at $27^{\circ} \mathrm{C}$; protoplasts were formed in modified $\mathrm{P}$ buffer $(7 \cdot 32 \%, \mathrm{w} / \mathrm{v}$, mannitol, $70 \mathrm{mM} \mathrm{NaCl}, 10 \mathrm{mM} \mathrm{MgCl}, 20 \mathrm{mM} \mathrm{CaCl}$ and $25 \mathrm{mM}$ TES buffer at $\mathrm{pH} 7 \cdot 2$ ); protoplast regeneration medium contained $7.32 \%(\mathrm{w} / \mathrm{v})$ mannitol and $1 \%(\mathrm{w} / \mathrm{v})$ maltose in place of sucrose and glucose, respectively; modified $\mathrm{T}$ buffer contained $25 \%(\mathrm{w} / \mathrm{v}$ ) PEG 4000 (Sigma) in modified P buffer. Transformants were selected by overlaying the agar with soft nutrient agar containing thiostrepton to give a plate concentration of $25 \mu \mathrm{g} \mathrm{ml}$.

Gene disruption. The apramycin-resistance gene in $\mathrm{pKC} 462 \mathrm{a}$ (Stanzak et al., 1986) was excised as a $1.5 \mathrm{~kb}$ Bam HI-Pst fragment and blunt-ended by treatment with the Klenow fragment of DNA polymerase I. pJV66 was digested with SfiI to remove a $130 \mathrm{bp}$ segment of the insert, and the ends of the residual vector fragment were also blunted. Ligation of the two blunt-ended products, transformation of $E$. coli TG1 with the ligation mixture and selection for apramycin resistance $\left(\mathrm{Apr}^{\mathrm{R}}\right)$ yielded strains containing the disruption vector pJV67. This was used to transform E. coli ET12567 (MacNeil et al., 1992); pJV67 reisolated from transformants of this DNA-methylasedeficient strain was used to transform S. venezuelae ISP5230. Approximately 200 colonies ( $\mu$ g plasmid DNA) ${ }^{-1}$ were obtained by initial selection for thiostrepton resistance $\left(T^{-}{ }^{2}{ }^{R}\right)$. Samples of genomic DNA extracted from 10 of these were fractionated by agarose gel electrophoresis and screened for hybridization to pHJL400. Colonies containing chromosomal DNA that hybridized to the probe were transferred to MYM agar

Table 1. Bacterial strains and plasmids used

\begin{tabular}{|c|c|c|}
\hline Strain & Genotype/phenotype & Source/reference \\
\hline \multicolumn{3}{|l|}{ Streptomyces venequelae } \\
\hline ISP5230 & Wild-type & Doull et al. (1985) \\
\hline VS654a and b & ISP5230 with integrated pJV67 & This study \\
\hline VS655a and b & $\begin{array}{l}\text { ISP5230 with ORF6 disrupted by a DNA fragment } \\
\text { conferring Apr }{ }^{\mathrm{R}}\end{array}$ & This study \\
\hline \multicolumn{3}{|l|}{ Escherichia coli } \\
\hline TG1 & $\begin{array}{l}\text { supE bsd } \Delta 5 \text { this(lac-pro } A B) \mathrm{F}^{\prime}\left(\text { traD } 36 \text { pro } A B^{+}\right. \\
\text {lacI lac } \mathrm{Z} \Delta \mathrm{M} 15)\end{array}$ & Carter et al. (1985) \\
\hline ET12567 & $d a m d c m b s d M$ & MacNeil et al. (1992) \\
\hline \multicolumn{3}{|l|}{ Plasmids and cosmid } \\
\hline $\mathrm{pKC} 462 \mathrm{a}$ & $\mathrm{Apr}^{\mathrm{R}}$ amp; bifunctional cosmid & Stanzak et al. (1986) \\
\hline pHJL400 & $\begin{array}{l}\text { tsr amp lac } Z^{\prime} \text { (bifunctional) } \\
\text { oHIL } 400 \text { with the } 2 \cdot 4 \mathrm{~kb} \text { Sact insert of plV } 60\end{array}$ & \\
\hline pJV67 & $\begin{array}{l}\text { pJV66 with the } 130 \text { bp } S f \text { II segment replaced by } \\
\text { a fragment conferring } A^{\mathrm{R}}{ }^{\mathrm{R}}\end{array}$ & This study \\
\hline pBluescript II SK(+) & amp lac $Z^{\prime}$ & Stratagene \\
\hline pJV85 & $\begin{array}{l}\text { pBluescript II SK(+) with a } 1.5 \mathrm{~kb} \text { Bam HI-PstI } \\
\text { insert conferring Apr }\end{array}$ & J.-Y. He, this laboratory \\
\hline $\mathrm{pJV} 60 / 61$ & $\begin{array}{l}\text { pBluescript II SK(+) with a } 2 \cdot 4 \mathrm{~kb} \text { SacI insert of } \\
\text { S. venezuelae } \mathrm{DNA} \text {; orientations in } \mathrm{pJV} 60 / 61 \\
\text { differ }\end{array}$ & This study \\
\hline
\end{tabular}


(Stuttard, 1982) containing $50 \mu \mathrm{g}$ apramycin $\mathrm{ml}^{-1}$, and the presumptive integrant colonies were subjected to two rounds of sporulation on MYM agar with apramycin but without thiostrepton. Plating of these spores yielded colonies sensitive to thiostrepton.

DNA sequencing and sequence analysis. The $2.4 \mathrm{~kb}$ fragment isolated from SacI-digested $\lambda$ LH7 DNA (Han et al., 1994) was subcloned in both orientations in the $\mathrm{SacI}$ site of pBluescript II $\mathrm{SK}(+)$. The recombinant phagemids (pJV60/61) were digested with exonuclease III and ligated to generate overlapping deletion clones. Single-stranded DNA templates were prepared using helper phage VCSM13 (Stratagene; Sambrook et al., 1989); they were sequenced by the dideoxy chain-termination method (Sanger et al., 1977) using Sequenase version 2.0 (US Biochemical) and $\left[{ }^{35} \mathrm{~S}\right] \mathrm{dA} T \mathrm{~T} \alpha \mathrm{S}$. When necessary, dGTP in sequencing reactions was replaced with 7-deaza-dGTP or dITP to resolve compressions. Nucleotide sequences were analysed with version 7.3 software developed by the Genetics Computer Group, Madison, WI, USA.

Southern hybridization. Genomic DNA was completely digested with $S_{a c I}$ and the fragments, separated by agarose gel electrophoresis, were transferred to nylon membranes (Southern, 1975). Digoxigenin (DIG)-dUTP was used to label DNA probes by the random priming method. Hybridization was carried out for $16 \mathrm{~h}$ at $65^{\circ} \mathrm{C}$ in a solution containing $5 \times \mathrm{SSC}(1 \times \mathrm{SSC}$ is $150 \mathrm{mM} \mathrm{NaCl}$ and $15 \mathrm{mM}$ sodium citrate, $\mathrm{pH} 7 \cdot 0), 2 \%(\mathrm{w} / \mathrm{v})$ Hammarsten casein (blocking reagent), $0.1 \%(\mathrm{w} / \mathrm{v}) \mathrm{N}$-lauroylsarcosine and $0.02 \%(\mathrm{w} / \mathrm{v})$ SDS. Membranes were washed twice at $65^{\circ} \mathrm{C}$ with $1 \times$ SSC containing $0.1 \%$ SDS, and then with $0.1 \times$ SSC containing $0.1 \%$ SDS. The labelled DNA was detected by a chemiluminescence procedure (Boehringer Mannheim).

Isolation of rabelomycin. Two cultures $(1000 \mathrm{ml})$ of each $S$. venezuelae mutant were treated with $6.0 \%(\mathrm{v} / \mathrm{v})$ ethanol at $6 \mathrm{~h}$ after inoculation and grown for a further $24 \mathrm{~h}$ under the conditions used for jadomycin production (Doull et al., 1993). The pooled cultures, adjusted to $\mathrm{pH} 3.2$ with $\mathrm{HCl}$, were filtered (Whatman no. 5 paper) under vacuum and extracted twice with $500 \mathrm{ml}$ ethyl acetate. The extract was evaporated in vacuo at $40^{\circ} \mathrm{C}$ and chromatographed on a column $(2 \cdot 0 \times 15 \mathrm{~cm})$ of silicic acid (J. T. Baker). Yellow fractions (containing rabelomycin) were eluted with ethyl acetate/toluene $(1: 9, \mathrm{v} / \mathrm{v})$ and evaporated to give $2.8 \mathrm{mg}$ orange oil. Further purification of this material by preparative TLC on $\mathrm{C}_{18}$ reverse-phase silica (E. Merck RP-18 $\mathrm{F}_{254}, 0.25 \mathrm{~mm}$ thickness) with water/acetonitrile $(20: 80, \mathrm{v} / \mathrm{v})$ as the mobile phase yielded $1.6 \mathrm{mg}$ rabelomycin $\left(R_{F} 0.72\right)$.

Analytical and spectroscopic procedures. Jadomycin and rabelomycin were monitored in culture extracts and chromatographic eluates by HPLC using a $\mathrm{C}_{18}$ reverse-phase silica column $(80 \times 4.0 \mathrm{~mm})$ and a programmed gradient of acetonitrile (solvent $A$ ) in acetonitrile/water $(1: 1, \mathrm{v} / \mathrm{v}$; solvent B) $; 0 \cdot 1 \%(\mathrm{v} / \mathrm{v})$ trifluoroacetic acid was included in both solvents $A$ and $B$. The content of solvent $A$ in the eluent changed linearly, and was $0,25,100,100$ and $0 \%$ at $0,3,6.5,7.5$ and 10 min, respectively. The retention times for jadomycin $\mathrm{B}$ and rabelomycin were 5.97 and 7.29 min, respectively. For analytical TLC, glass plates $(5 \times 20 \mathrm{~cm})$ coated with a $250 \mathrm{~mm}$ thickness of silica gel $60 \mathrm{~F}_{254}$ (E. Merck) were used. With toluene/ethyl acetate $(1: 1, \mathrm{v} / \mathrm{v})$ as the solvent, the $R_{F}$ values for jadomycin $B$ and rabelomycin were $0 \cdot 21$ and $0 \cdot 16$, respectively.

${ }^{1} \mathrm{H}$ - and ${ }^{13} \mathrm{C}$-NMR spectra were obtained with a Bruker AMX 500 spectrometer $\left(500 \mathrm{MHz}\right.$ for ${ }^{1} \mathrm{H} ; 125 \mathrm{MHz}$ for $\left.{ }^{13} \mathrm{C}\right)$. The ${ }^{1} \mathrm{H}$ - and ${ }^{13} \mathrm{C}$-NMR spectra (recorded in $\mathrm{CDCl}_{3}$ ) of authentic rabelomycin and the product from $S$. venezuelae VS655a were identical and agreed well with the published spectra, except that under our conditions both the authentic and $S$. venezuelae samples contained a ${ }^{13} \mathrm{C}$ resonance at 72.2 p.p.m. in place of one at 76.95 p.p.m. in the ${ }^{13} \mathrm{C}-\mathrm{NMR}$ spectrum reported for synthetic $( \pm)$ rabelomycin by Krohn \& Khanbabaee (1994). Imamura et al. (1982) reported a resonance at 71.6 p.p.m.

\section{RESULTS}

\section{Sequence and analysis of the $\mathbf{2 . 4} \mathrm{kb} \mathrm{Sacl}$ fragment from S. venezuelae}

A $2.4 \mathrm{~kb}$ SacI fragment from the $S$. venezuelae DNA insert in $\lambda$ phage LH7 (Han et al., 1994) was subcloned in $\mathrm{pHJL} 400$ to give pJV66. The nucleotide sequence (Fig. 2) showed that one end of the pJV66 insert coincided with the 3'-end of the cyclase-dehydratase gene (ORF4) in the PKS gene cluster for jadomycin B biosynthesis (Han et al., 1994). Analysis of the sequence of the entire $2.4 \mathrm{~kb}$ fragment with the FRAME (Bibb et al., 1984) and CODONPREFERENCE (Devereux $e t$ al., 1984) programs showed, in addition to the incomplete ORF4, one complete ORF (ORF6) and a second incomplete one (ORF7). ORFs 6 and 7 lie downstream of, and are transcribed in the same direction as, the ORFs of the PKS cluster (Fig. 3). ORF6 is separated by only 1 bp of non-coding DNA from the 3'end of ORF4; it starts with an ATG at nt 530-532, which is preceded $9 \mathrm{nt}$ upstream, and thus within the ORF4 coding sequence (see Fig. 2), by a plausible ribosomalbinding site. The stop codon for ORF6 is the TGA at nt 2105-2107. ORF7 starts with an ATG at nt 2131-2133, and is thus separated by $22 \mathrm{nt}$ from the stop codon of ORF6; a ribosomal-binding site is present 9 nt upstream. No in-frame stop codon was present in the sequenced region downstream of the ORF7 start codon.

\section{Amino acid sequence deduced for ORF6}

ORF6 encodes a protein of 525 amino acids, with an estimated $M_{\mathrm{r}}$ of 55126 , and an isoelectric point of 6.41 . Comparison of the deduced amino acid sequence of ORF 6 with database sequences showed significant similarity to two groups of oxygenases: one catalyses the introduction of hydroxyl groups into polyketide antibiotics; the other participates in the catabolism of aromatic compounds. No similarity was detected to the sequence of P-450 cytochromes that hydroxylate erythromycin aglycone (Haydock et al., 1991; Weber et al., 1991; Stassi et al., 1993); neither the oxygen-binding site nor the haemligand pocket characteristic of these monooxygenases was present (Nebert \& Gonzales, 1987; Poulos et al., 1987; Omer et al., 1990). In the group of polyketide hydroxylases, the strongest resemblance $[45.5 \%$ identity in comparisons with the GAP program (Devereux et al., 1984)] was to the product of a putative oxygenase gene $(u r d F)$ involved in biosynthesis of the angucycline antibiotic urdamycin A in Streptomyces fradiae (Rohr et al., 1989); other similar gene products were hydroxylases such as RdmE (27.5\% identity; Niemi \& Mäntsälä, 1995) of Streptomyces purpurascens, TcmG $(25.0 \%$ identity) involved in tetracenomycin biosynthesis in Streptomyces glaucescens (Decker et al., 1992), DnrF (22.7\% identity) of 
ORF 4 end ORF 6 --->

CGGGCCACCCTCGGGTACGCCAAGGCCTACGCCGAGGGCAAGCGCTGACATGACGGAGC $\begin{array}{lllllllllllllllllllll}R & A & T & L & G & Y & A & K & A & Y & A & \bar{E} & G & K & R & * & M & T & E & P\end{array}$ CCGCCGGGCAGGAGCGCCCGCACCGGAGTCCCCGGACGCCCCGGACACCCCGGTCCTCCT 600 $\begin{array}{lllllllllllllllllllll}R & R & A & G & A & P & A & P & E & S & P & D & A & P & D & T & P & V & L & \text { L }\end{array}$ GGACGCCGACGTCGTCGTCATCGGCGCCGGGCCCACCGGCCTGATGCTCGCCGGCGAACT $\begin{array}{llllllllllllllllllll}D & A & D & \text { V } & \text { V } & \text { V } & \text { I } & G & \text { A } & G & \text { P } & \text { T } & G & \text { L } & \text { M } & \text { L } & \text { A } & G & \text { E } & \text { L }\end{array}$ GCGGCTCGGCGGCGCGGACGTGATCGTCCTGGAGAGCCGGGAGACCCCCACCACCGAGTC $\begin{array}{llllllllllllllllllll}R & I & G & G & A & D & V & I & V & L & E & S & R & E & T & P & T & T & E & S\end{array}$ CCGGGCCTCCACGCTGCACGCCCGCACGATGGAACTGCTCGACGACCGCGGGCTGCTCAC $\begin{array}{llllllllllllllllllll}R & A & S & T & \text { L } & \text { H } & \text { A } & \text { R } & \text { T } & \text { M } & \text { E } & \text { L } & \text { L } & \text { D } & \text { D } & \text { R } & \text { G } & \text { L } & \text { L } & T\end{array}$ CCCGCTCGGCACTCCGCCGTCGGAGCCCCGCGGCGGGCACTTCGGCGGCATCCCGCTCGA 840 $\begin{array}{llllllllllllllllllllllllll}P & I & G & T & P & P & S & E & P & R & G & G & H & F & G & G & I & P & L & D\end{array}$ CCTGACCCTGCCCGGTCGGCACCCCGGGCAGTGGAAGGTCGAGCAGACCCGGACCGAGGC $\begin{array}{llllllllllllllllllll}\text { L } & \text { T } & \text { L } & \text { P } & G & \text { R } & \text { H } & \text { P } & \text { G } & Q & \text { W } & \text { K } & \text { V } & \text { E } & \mathbf{Q} & \text { T } & \text { R } & \text { T } & \mathbf{E} & \mathbf{A}\end{array}$ GCTGCTCCAGGAGTGGGCCACCGGCCTCGGGGCCGACGTCCGACGCGGCCACACCCTGCG 960 $\begin{array}{lllllllllllllllllllll}L & I & Q & E & \text { W } & A & T & G & L & G & A & D & V & R & R & G & H & T & L & R\end{array}$ CTCCCTCACGGTGACGGAGACGTACGCCGAGGCCGGAGCCACCGGCCCCGGCGGCCGTGA 1020 $\begin{array}{llllllllllllllllllllll}S & L & T & V & T & E & T & Y & A & E & A & G & A & T & G & P & G & G & R & D\end{array}$ CGTGCGCGTGCGGGCCCGGTACGCCGTGGGCTGCGACGGGGAGCGGACGACCGTACGGGC 1080 $\begin{array}{lllllllllllllllllll}V & R & V & R & A & R & Y & A & V & G & C & D & G & E & R & T & T & V & R \\ S f i I\end{array}$

CCTGGCCGGGGCGGAGTTCCCCGGCCAGGAGGCCCGGCGCGAACTGCTCCGGGCCGATGT 1140 $\begin{array}{lllllllllllllllllllll}L & A & G & A & E & F & P & G & Q & E & A & R & R & E & \text { L } & \text { I } & R & A & D & V\end{array}$ GGCCGGGATCGACGTCCCCGACCGGCGCTTCCAGCGGCTGCCCGGCGGACTGGCCGTCGC 1200 $\begin{array}{llllllllllllllllllll}A & G & I & D & V & P & D & R & R & F & Q & R & \text { L } & \text { P } & G & G & \text { L } & A & V & A\end{array}$ CGCGTGCCGCAACGGCGTCACCCGGGTCATGGTCCACGAGTTCGGCAGGCCCGCCGTGGC 1260 $\begin{array}{llllllllllllllllllllll}A & C & R & N & G & V & T & R & V & M & V & H & E & F & G & R & P & A & V & A\end{array}$ CAGGACCGGCGAGCCGGAGTTCCGCGAGGTCGTGGACGTGTGGAAGCGGGTCACGGGGGA 1320 $\begin{array}{llllllllllllllllllll}R & T & G & E & P & E & F & R & E & V & V & D & V & W & K & R & V & T & G & E\end{array}$ GGACATCACGGCGGGCACGCCGCTCTGGGTGAACTCCTTCCACGACGCCAACCGGCAGCT 1380 $\begin{array}{llllllllllllllllllllll}D & I & T & A & G & T & P & L & \text { W } & \text { V } & \text { N } & \text { S } & \text { F } & \text { H } & \text { D } & \text { A } & \text { N } & \text { R } & Q & \text { L }\end{array}$ CACCCGCTACCGGGACGGGCGCGTCCTGTGGGCGGGGGACGCCGCCCACCAGCAGATGCC 1440 $\begin{array}{lllllllllllllllllllll}T & R & Y & R & D & G & R & V & \text { L } & \text { W } & \text { A } & G & D & A & A & H & Q & Q & M & P\end{array}$ GATCGGCGGCCAGGCCCTCAACCTGGGGCTCCAGGACGCCGTCAACCTCGGCTGGAAGCT 1500 $\begin{array}{lllllllllllllllllllll}\text { I } & G & G & Q & A & \text { L } & \text { N } & \text { L } & G & \text { L } & Q & \text { D } & \text { A } & \text { V } & \text { N } & \text { L } & G & \text { W } & \text { K } & \text { L }\end{array}$ CGCCGCCGTGGTCCGCGGCACGGCGCCGGACGGGCTGCTCGACACCTACCACGACGAGCG 1560 $\begin{array}{llllllllllllllllllll}A & A & V & V & R & G & T & A & P & D & G & L & L & D & T & Y & H & D & E & R\end{array}$ GCACGCCGTCGGCCGCCAGGTCCTCGGCAACATCAGGGCCCAGGCCCTGCTGCTCCTCGG 1620 $\begin{array}{llllllllllllllllllll}H & A & V & G & R & Q & V & L & G & N & I & R & A & Q & A & \text { L } & \text { L } & \text { L } & \text { L } & G\end{array}$ CGGGCCCGAGGCGGAGCCCGTCCGCTCCCTCCTCGGCGGGCCCGAGGCGGAGCCCGTCCG 1680 $\begin{array}{lllllllllllllllllllllll}G & P & E & A & E & P & V & R & S & \text { L } & \text { L } & G & G & P & E & A & E & P & V & R\end{array}$ CTCCCTCCTCGGCCCGCTCATCGCCCTGGACGACGTGCGGGCGCACCTGGCCGGCAAGGT 1740 $\begin{array}{llllllllllllllllllllll}S & \text { L } & \text { L } & G & \text { P } & \text { L } & \text { I } & \text { A } & \text { L } & \text { D } & \text { D } & \text { V } & \text { R } & \text { A } & \text { H } & \text { L } & \text { A } & \text { G } & \text { K } & \text { V }\end{array}$ CTCAGGACTCGACATCCGGTACGGGGCCGGGGCGGCGGACGTGCATCCGCTGACCGGCAC 1800 $\begin{array}{llllllllllllllllllll}S & G & \text { L } & D & \text { I } & R & Y & G & A & G & A & A & D & V & H & P & \text { L } & T & G & T\end{array}$ CCGGCTGCCCCGCACGGCCCTCGTGGACGACGGCCGCGAGGGCCTGCACCCGTCGCTGCG 1860 $\begin{array}{llllllllllllllllllll}R & \text { L } & \text { P } & R & \text { T } & \text { A } & \text { L } & \text { V } & \text { D } & \text { D } & G & \text { R } & \text { E } & G & \text { L } & \text { H } & \text { P } & \text { S } & \text { L } & R\end{array}$ GGCCGGCCAGGGCCTTGTCCTGACGCTGGACCCGAGCGGCACCGGGCCCGGGACCGGAGC 1920 $\begin{array}{lllllllllllllllllllll}A & G & Q & G & \text { I } & \text { V } & \text { L } & \text { T } & \text { I } & \text { D } & \text { P } & \text { S } & G & \text { T } & G & \text { P } & G & \text { T } & G & A\end{array}$ GGCGGCGGCCGCCGCCTGGGCCGGCCGGGTCGGCACCGCCGTGGCCAGGCCCGTGCCCGG 1980 $\begin{array}{lllllllllllllllllllll}\text { A } & \text { A } & \text { A } & \text { A } & \text { A } & \text { W } & \text { A } & \text { G } & \text { R } & \text { V } & \text { G } & \text { T } & \text { A } & \text { V } & \text { A } & \text { R } & \text { P } & \text { V } & \text { P } & \text { G }\end{array}$ CGGCGTCCTCGACGGACTCGACGCCGTCCTCGTACGGCCCGACGGCTACCTCGCCTGGAC 2040 $\begin{array}{llllllllllllllllllll}G & \text { V } & \text { L } & D & G & \text { L } & \text { D } & \text { A } & \text { V } & \text { L } & \text { V } & \text { R } & \text { P } & \text { D } & G & \text { Y } & \text { L } & \text { A } & \text { W } & T\end{array}$ CTCGGCCGACGGCGCGGGACCGGAAGCGGCCCTGCACCGCTGGTTCGGCGCCCCCACCCA 2100

$\begin{array}{llllllllllllllllllll}S & A & D & G & A & G & P & E & A & A & \text { L } & H & R & \text { W } & \text { F } & G & \text { A } & \text { P } & \text { T } & \text { H }\end{array}$ ORF7 --->

CCTCTGAACCCCGACGAAGGACCGAGAACCATGCCTCTGATCAACCCCGAGACGGCTAC 2160

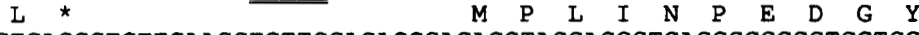
CTGACCGTCTTCAACCTCTTCGAGACCGAGACCTACGACGGTCAGGCCCGCGTCGTCGAC 2220 $\begin{array}{llllllllllllllllllll}L & T & V & F & N & \text { L } & F & E & T & E & T & Y & D & G & Q & A & R & V & V & D\end{array}$ GAGATGAAGGACATCGTCGACAACGCCACGTACCCCGGCTGGATCTCCTCCACCGTGCAC 2280

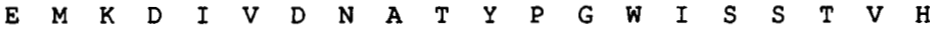
GCCGGCGTCGACACCCCGGGCACCCTCAACTACATCCAGTGGCGCAGCCTCGCCGACCTG 2340

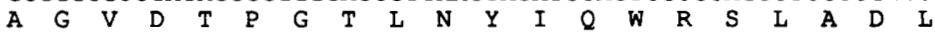
GAGGCGCGCTACCAGGGGCAGAAGTTCCAGAAGAAGACCGTGCCGCTCTTCGACCAGCTC 2400 $\begin{array}{llllllllllllllllllll}E & A & R & Y & Q & G & Q & K & F & \underset{S a C I}{Q} & K & T & V & P & L & F & D & Q & L\end{array}$

GCCACCTCCGTGAAGCTGCTCAAGACGGAGCTC

$\begin{array}{llllllllllllll}\text { A } & \text { T } & \text { S } & \text { V } & \text { K } & \text { L } & \text { L } & \text { K } & \text { T } & \text { E } & \text { L }\end{array}$
Fig. 2. Nucleotide sequence of the $2.4 \mathrm{~kb}$ Sacl segment of $S$. venezuelae DNA excised from $\lambda$ clone $\mathrm{LH} 7$, omitting the region previously sequenced (Han et al., 1994). Deduced amino acid sequences are shown for ORF6 and a part of ORF7 (see Fig. 3). Putative ribosome-binding sites are doubly underlined. Significant restriction sites are underlined. Translational start codons locate the beginning of ORFs; asterisks identify stop codons.
Streptomyces peucetius, used for 11-hydroxylation of aklavinone in daunorubicin biosynthesis (Hong et al., $1994)$, SchC (24.3\% identity) involved in spore pigment formation in Streptomyces balstedii (Blanco et al., 1993) and OtcC involved in oxytetracycline biosynthesis in Streptomyces rimosus (cited in Blanco et al., 1993). The ORF6 product did not resemble any of the products of act $\mathrm{VA}$ implicated in ring hydroxylation of actinorhodin intermediates (Caballero et al., 1991).
The second group of oxygenases to which the ORF6 product showed sequence similarity participates in the degradation of aromatic compounds. Here the extent of the similarity matched that shown to most polyketide hydroxylases: e.g. $26.2 \%$ identity with pentachlorophenol 4-monooxygenase (PcpB) from a Flavobacterium species (Orser et al., 1993); 22.2\% identity with 2,4dichlorophenol 6-monooxygenase (TfdB) of Alcaligenes eutrophus (Perkins et al., 1990); and 20.7\% identity with 

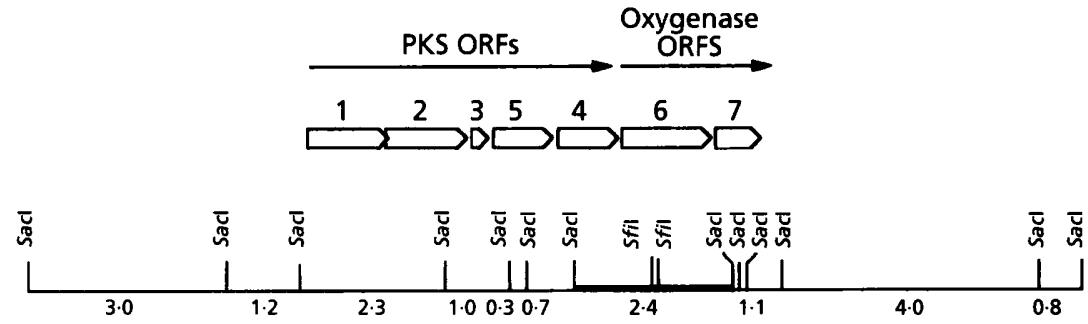

Fig. 3. Sacl restriction map of the $16.5 \mathrm{~kb}$ fragment of S. venezuelae ISP5230 genomic DNA insert from $\lambda$ clone $\mathrm{LH} 7$. The $2.4 \mathrm{~kb}$ region subcloned in pBluescript II SK(+) and sequenced is shown as a thickened line; the Sfil markers within it locate the Sfil-sfil segment replaced with an apramycinresistance gene. Arrows above the restriction map show the locations and orientations of the PKS cluster (ORFs 1-5) and putative oxygenase genes (ORFs 6 and 7).

$\begin{array}{lr}\text { (a) } & \\ \text { ORF6 } & 27 \\ \text { TCMG } & 21 \\ \text { SChC } & 16 \\ \text { OtCC } & 4 \\ \text { DnrF } & 9 \\ \text { PCLO } & 16 \\ \text { TFDB } & 8 \\ \text { PHEA } & 37\end{array}$

(b)

ORF6 288

TCMG 327

SchC 304

OtcC 279

DnrF 301

PCLO 289

TFDB 302

PHEA 320

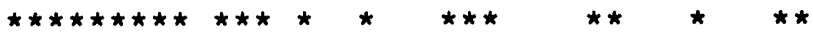
DVVVIGAGPTGLMLAGELRLGGADVIVLESRETPTTESR PVLIVGGGLTGLSAALFLSOHGVSCRLVEKHRGTTVLTR PVIVVGGSLVGLSTSVFLGRLGVRHMLVERHAGTSVHPR DVVIAGAGPTGLMLACELRLAGARTLVLERLAERVDFSK DVLVVGGGLGGLSTALFLARRGARVLLVERHASTSVLPK AVLIVGGGTTGL IAANELLRRGVSCRMIDRLPVAHQTSK DVLVVGTGPAGASAGALLARYGVRTMLINKYNWTAPTPR DVLTVGSGPAGSSAAMFLSTQGISNIMITKYRWTANTPR
\end{abstract}

65
59
54
39
48
54
46
75

65

48

54

75

Fig. 4. Alignment by PILEUP (Genetics Computer Group, University of Wisconsin, Madison, WI, USA) of segments of the amino acid sequences deduced from ORF6 and database hydroxylases. The similarity around two motifs present in FADand NADPH-dependent enzymes is shown. (a) A putative ADP-binding domain in the N-terminal region. (b) A putative ribityl-binding domain in the C-terminal region. Highly conserved amino acids are indicated by asterisks. The aspartic acid residue important for binding the ribityl chain of FAD is indicated by an arrow and is in boldface. TcmG, tetracenomycin C hydroxylase from S. glaucescens; SchC, a putative hydroxylase involved in forming spore pigment in S. halstedii; OtcC, anhydrooxytetracycline monooxygenase from S. rimosus; DnrF, aklavinone 11-hydroxylase from S. peucetius subsp. caesius; PCLO, pentachlorophenol 4-monooxygenase from a Flavobacterium species; TFDB, 2,4-dichlorophenol hydroxylase from Alcaligenes eutrophus; PHEA, phenol monooxygenase from a Pseudomonas species (see text for references).

phenol 2-monooxygenase (PheA) from a Pseudomonas species (Nurk et al., 1991).

Among all sequences showing similarity, the resemblance was particularly strong around two motifs present in FAD- and NADPH-dependent hydroxylases. One of the motifs was the $\beta-\alpha-\beta$ fold associated with binding of the ADP moiety of FAD (Wierenga et al., 1985, 1986; Eggink et al., 1990); it was located near the $\mathrm{N}$-terminus of the polypeptide (Fig. 4a). The second motif contains an aspartic acid that participates in binding the ribityl substituent of the flavin moiety of FAD (Fig. 4b; Russel \& Model, 1988; Eggink et al., 1990). The extent of the sequence similarity between the ORF6 product and both groups of oxygenases suggests that ORF6 encodes an enzyme that hydroxylates an aromatic polyketide intermediate in jadomycin B biosynthesis, and that this reaction leads to scission of the angucycline $B$ ring (see below).

From comparisons with the database, the amino acid sequence deduced from the incomplete ORF7 is similar to only two known proteins: $\mathrm{TcmH}$ of $S$. glaucescens, and actVA-ORF6 of $S$. coelicolor $\mathrm{A} 3(2)$. TcmH encodes an anthraquinol oxidase catalysing hydroxylation at $\mathrm{C}-5$ of a tetracenomycin $\mathrm{C}$ biosynthetic intermediate, $\mathrm{TcmF} 1$, to generate the corresponding quinone, TcmD3 (Shen \& Hutchinson, 1993b; Hutchinson, 1994). The product of 
(a)
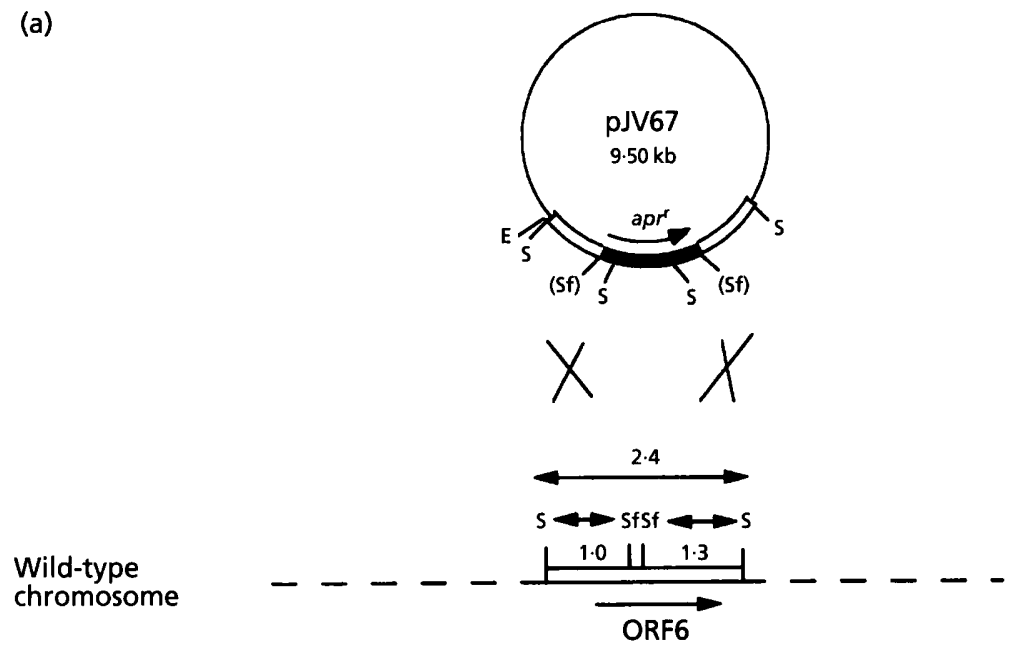

(b)
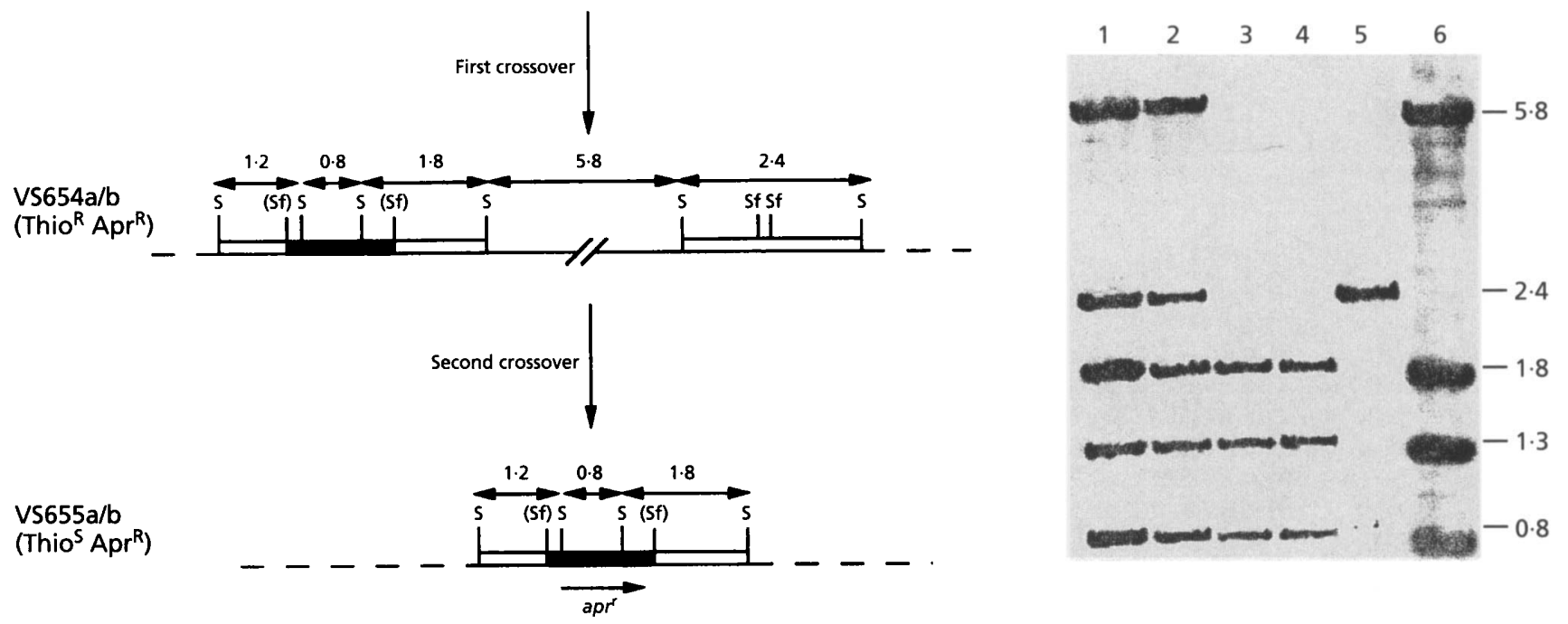

Fig. 5. (a) Diagram showing the disruption of ORF6 by insertion of an apramycin-resistance gene (apr'). Wild-type S. venezuelae was transformed with the pJV67 and $\operatorname{Thio}^{R} \mathrm{Apr}^{R}$ colonies generated by the first crossover between homologous DNA in the plasmid and chromosome were propagated in the presence of apramycin. Those in which a second crossover occurred were selected by their Thio ${ }^{S}$ Apr $^{R}$ phenotype. The filled arc in pJV67 represents the apramycinresistance gene introduced into ORF6 by replacing an Sfil-Sfil fragment; adjacent open arcs represent cloned $S$. venezuelae DNA containing ORF6. The corresponding regions in chromosomal DNA are represented by filled and open bars. S, Sacl; E, EcoRl; Sf, Sfil. The Sfil sites lost during construction of pJV67 are in parentheses. (b) Southern hybridization of genomic and pJV67 DNA digested with Sacl and probed with pJV67. Lanes: 1, VS654a; 2, VS654b; 3 , VS655a; 4, VS655b; 5, ISP5230; 6, pJV67. Numbers are the sizes (in kb) of hybridizing Sacl fragments. Chemiluminescent bands were detected on X-ray film and recorded with a Hewlett Packard ScanJet IIcx/T using Adobe Photolab software.

act VA-ORF6 probably has a similar function (Caballero et al., 1991; Fernandez-Moreno et al., 1994).

\section{Targeted disruption of ORF6 in the chromosome}

A gene disruption vector was constructed from $\mathrm{pHJL} 400$, a bifunctional E. coli-Streptomyces plasmid that lacks the partition function of the SCP2* parent and is thus segregationally unstable in streptomycetes (Larson \& Hershberger, 1986). The $2.4 \mathrm{~kb}$ SacI fragment of $S$. venezuelae DNA cloned in pHJL400 to furnish pJV66 contained a $130 \mathrm{bp}$ Sfil-SfiI segment lying within the confines of ORF6; this was replaced with a $1.5 \mathrm{~kb}$ fragment containing the apramycin-resistance gene from
pKC462a (Stanzak et al., 1986), thereby forming the ORF6 disruption vector pJV67 (Fig. 5a). To circumvent a restriction system recognizing methylated DNA apparently present in S. venequelae ISP5230 (Han et al., 1994), pJV67 was first used to transform a DNA-methylationdeficient strain of E. coli (MacNeil et al., 1992), and reisolated for use with the streptomycete. $S$. venezuelae transformants propagated without thiostrepton selection yielded Thio $^{\mathrm{R}} \mathrm{Apr}^{\mathrm{R}}$ and $\mathrm{Thio}^{\mathrm{S}} \mathrm{Apr}^{\mathrm{R}}$ colonies. SacI digests of genomic DNA from two colonies of each type were probed by Southern hybridization with pJV67 to detect single and double crossover events (Fig. 5b). Wild-type genomic DNA gave the expected signal at $2.4 \mathrm{~kb}$, whereas the DNA from VS654a and VS654b $\left(\right.$ Thio $^{\mathrm{R}} \mathrm{Apr}^{\mathrm{R}}$ ) gave a 
signal at $5.8 \mathrm{~kb}$ for vector DNA, as well as signals at $0 \cdot 8$, 1.2 and $1.8 \mathrm{~kb}$ for the apramycin-resistance gene and flanking DNA segments. The signals were consistent with an initial integration of pJV67 into the chromosome of $S$. venezuelae ISP 5230 by a single crossover. The absence of a signal at $5.8 \mathrm{~kb}$ in VS655a and VS655b (Thio ${ }^{\mathrm{S}} \mathrm{Apr}^{\mathrm{R}}$ ) indicated that a second crossover had excised the vector DNA. As a result, the ORF6 oxygenase gene in the chromosome was replaced with the sequence disrupted by insertion of the apramycin-resistance gene.

\section{Characterization of metabolites}

Analysis by HPLC of wild-type and mutant $S$. venezuelae ISP5230 strains grown under conditions that elicit jadomycin B production (Doull et al., 1994) showed low yields of the antibiotic (10\% of wild-type levels) in strains VS654a and VS654b carrying integrated pJV67. Accompanying the jadomycin $\mathrm{B}$ was a second product not encountered in the wild-type strain. The replacement mutants (VS655a and VS655b) produced only this product; no jadomycin B could be detected. Further analysis of cultures by TLC, and recovery of the products by chromatography of culture extracts on silicic acid columns, established that the substance accumulated by replacement mutants was a yellow antibiotic indistinguishable by direct comparison from an authentic specimen of (-)-rabelomycin (Liu et al., 1970). The presence of a mixture of jadomycin B and rabelomycin in strains with pJV67 integrated by a single crossover was also confirmed by TLC.

\section{DISCUSSION}

Considerable progress has been made recently in clarifying the molecular genetics of polyketide antibiotic biosynthesis in actinomycetes, and many of the important principles have been established (McDaniel et al., 1993; Shen \& Hutchinson, 1993a; Hopwood et al., 1994). One of the areas that remains to be fully explored is the molecular basis for the remarkable diversity of the polyketide family of secondary metabolites. Even within the subgroup distinguished by its use of acetate starter and malonate extender units, there is a wide range of structural options; these depend not only on the number of malonate units introduced, but also on the pattern in which the growing chain is folded, and ancillary reactions that modify specific sites on the chain. Although the roles of some PKS genes can be predicted from their sequence similarity to those of fatty acid biosynthesis (Hopwood \& Sherman, 1990), others can not. The availability of sets of cloned PKS genes for a variety of metabolites has therefore been exploited to establish the rules for 'programming' polyketide-based structures. By determining the biochemical consequences of precisely replacing individual genes in well-defined PKS gene clusters with their counterparts from other clusters, plausible roles have been assigned to several PKS genes (Sherman et al., 1992; Khosla et al., 1993; Kim et al., 1994).

Fig. 6 outlines the steps that might lead to the jadomycin
B structure. Assembly of a polyketide from acetyl-CoA and nine molecules of malonyl-CoA would be catalysed by a PKS complex encoded by ORFs 1-3. Correct cyclization of the polyketide chain probably requires the cyclase-dehydratase product of ORF4; an additional enzyme analogous to TcmI (Summers et al., 1993; Shen \& Hutchinson, 1993b) may be needed to complete the cyclization. The structural features of particular interest in jadomycin B are the angular ring fusion pattern and the interruption of a predicted polyketide carbon chain by a nitrogen atom that seems likely to originate biosynthetically from isoleucine supplied in the medium (Doull et al., 1994). The component (or components) in the jad cluster that influences the chain folding and cyclization to generate an angular, rather than the more common linear ring fusion pattern, has yet to be determined. Introduction of an isoleucine moiety can plausibly be accounted for by ring scission in a polyketidederived intermediate, followed by a reaction inserting isoleucine at the reactive centre thus created.

To open ring B of a cyclized polyketide intermediate, monooxygenase or dioxygenase activity, or both acting sequentially as in the metabolism of phenolic compounds by micro-organisms (Perkins et al., 1990), might be predicted. The similarity between the ORF6 product and numerous monooxygenases that modify polyketide and aromatic compounds suggests that this ORF encodes a protein involved in the scission of ring B. If so, distuption of ORF6 would be expected to block ring opening, and cause an accumulation of earlier intermediates or their shunt products. The isolation of rabelomycin, an angucycline antibiotic discovered in cultures of Streptomyces olivaceus (Liu et al., 1970) and later identified along with angucycline antibiotics of the vineomycin group as a product of Streptomyces matensis subsp. vineus (Imamura et al., 1982), supports the presumption that jadomycin B is biosynthesized via an angular polyketide intermediate. It is noteworthy that in the comparison with database sequences, the deduced ORF6 product showed closest identity to $u r d F$, which encodes an oxygenase implicated in the biosynthesis of urdamycin A, an angucycline antibiotic (Rohr et al., 1989) with structural similarities to jadomycin B. Presumably the gene clusters for the two biosynthetic pathways have a close evolutionary relationship.

The absence of a hydroxyl group at C-10 in rabelomycin indicates that the carbonyl group at the corresponding position in the polyketide is reduced by a ketoreductase (presumably the product of ORF5; Han et al., 1994) and lost by dehydration before ring B is opened. Similar timing for a decarboxylation step is implied by the absence of a carboxyl group at C-2 in rabelomycin. In contrast, loss of the C-3 hydroxyl in a dehydration reaction aromatizing ring A may occur after ring $B$ is opened, and the lack of sugar substituents on rabelomycin suggests that glycosylation is also a late reaction. Similarities in the amino acid sequences of anthrone oxidases and that deduced for the incomplete ORF7 product implicates this $\mathrm{ORF}$ in the introduction of oxygen at $\mathrm{C}-12$ to generate a quinone group in rabelomycin. A conserved histidine in 


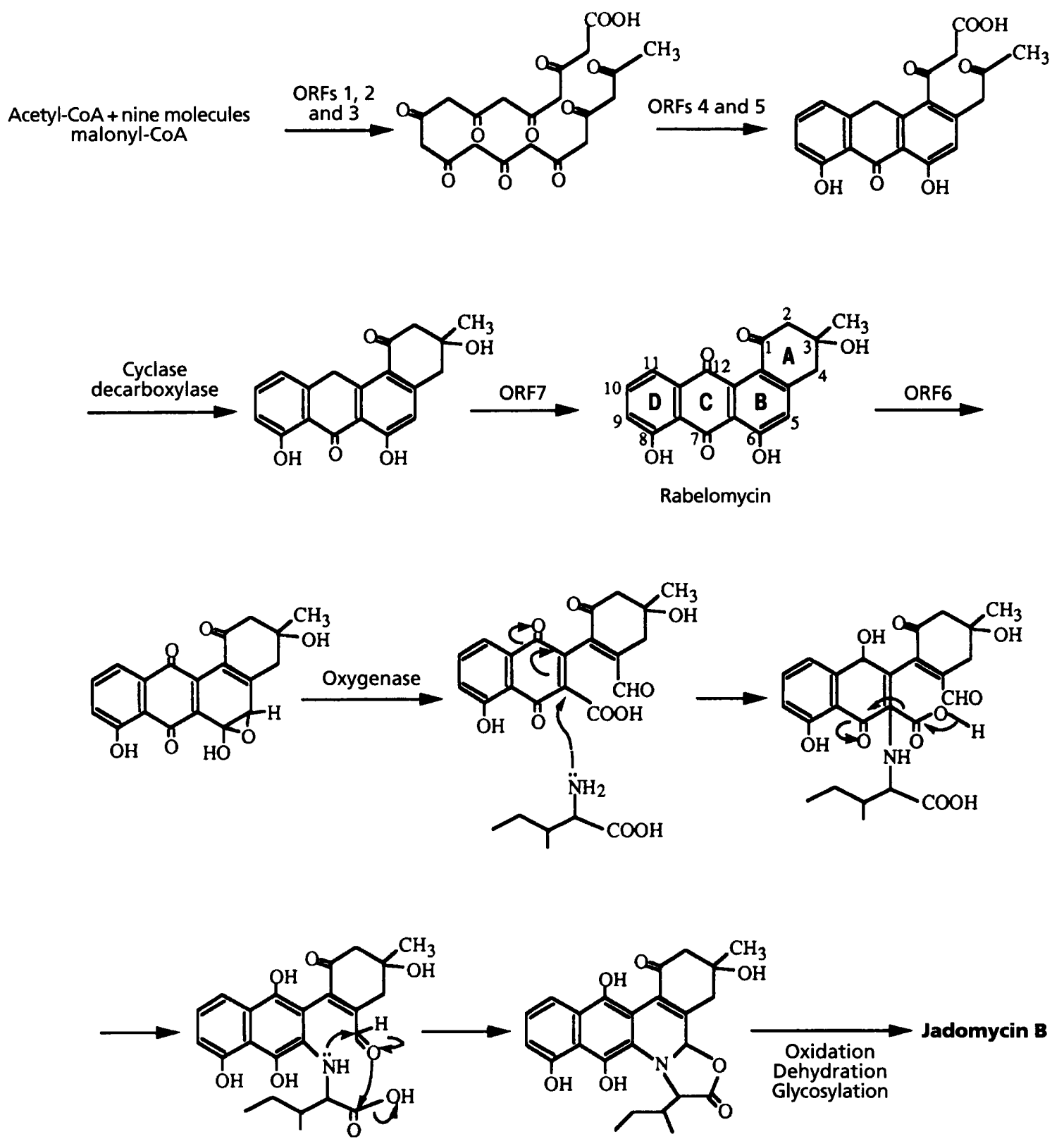

Fig. 6. Outline of a tentative pathway for the biosynthesis of jadomycin B.

the amino acid sequences deduced for $t c m H$, act $\mathrm{VA}$ ORF6 and ORF7 of $S$. venezuelae is consistent with the essential role predicted for this amino acid in $\mathrm{TcmH}$ activity (Shen \& Hutchinson, 1993a). Preliminary data indicate that ORF7 encodes a large protein containing more than 200 amino acids. It is, therefore, substantially bigger than either $\mathrm{TcmH}$ (81 amino acids) or the product of actVA-ORF6 (113 amino acids). Although ORF7 is downstream of ORF6, the presence of the quinone group in rabelomycin implies that the ORF7 product acts earlier than that of ORF6 in the biosynthetic pathway. Accumulation of the quinonoid intermediate rather than the corresponding anthrone in the replacement mutants is consistent with evidence from restriction analysis that the apramycin-resistance gene in PJV67 has the same orientation as ORF6, in which it is inserted (see Fig. 5a). Thus expression of ORF7, which has the same orientation as ORF6, is not prevented; it may continue by readthrough from a promoter in the PKS gene cluster, or be initiated from the promoter of the apramycin-resistance gene.

\section{ACKNOWLEDGEMENTS}

We are grateful to Janice Doull of the Biology Department at Mount Saint Vincent University for exchange of information about jadomycin B production. We thank C. Hershberger and R. Nagarajah Rao of Eli Lilly and Company for providing pHJL400 and pKC462a, respectively; also, D. J. MacNeil of 
Merck for a culture of E. coli ET12567, and Derek Hook of Bristol-Myers, Squibb, for an authentic specimen of rabelomycin. The research was supported by the Natural Sciences and Engineering Research Council of Canada.

\section{REFERENCES}

Ayer, S. W., Mclnnes, A. G., Thibault, P., Walter, J. A., Doull, J. L., Parnell, T. \& Vining, L. C. (1991). Jadomycin, a novel $8 \mathrm{H}-$ benz[b]oxazolo[3,2-f]phenanthridine antibiotic from Streptomyces venequelae ISP5230. Tetrabedron Lett 32, 6301-6304.

Bibb, M. J., Findlay, P. R. \& Johnson, M. W. (1984). The relationship between base composition and codon usage in bacterial genes and its use in the simple and reliable identification of proteincoding sequences. Gene 30, 157-166.

Blanco, G., Pereda, A., Brian, P., Mendez, C., Chater, K. F. \& Salas, J. A. (1993). A hydroxylase-like gene product contributes to synthesis of a polyketide spore pigment in Streptomyces balstedii. J Bacteriol 175, 8043-8048.

Caballero, J. L., Martinez, E., Malpartida, F. \& Hopwood, D. A. (1991). Organization and functions of the actVA region of the actinorhodin biosynthetic gene cluster of Streptomyces coelicolor. Mol \& Gen Genet 230, 401-412.

Carter, P., Bedovelle, H. \& Winter, G. (1985). Improved oligonucleotide site-directed mutagenesis using M13 vectors. Nucleic Acids Res 13, 4431-4443.

Decker, H., Motamedi, H. \& Hutchinson, C. R. (1992). Nucleotide sequences and heterologous expression of $\operatorname{tcm} G$ and $t \mathrm{~cm} P$, biosynthetic genes for tetracenomycin $\mathrm{C}$ in Streptomyces glaucescens. J Bacteriol 175, 3876-3886.

Devereux, J., Haeberli, P. \& Smithies, O. (1984). A comprehensive set of sequence analysis programs for the VAX. Nucleic Acids Res 12, 387-395.

Doull, J. L., Ahmed, Z., Stuttard, C. \& Vining, L. C. (1985). Isolation and characterization of Streptomyces venequelae mutants blocked in chloramphenicol biosynthesis. J Gen Microbiol 131, 97-104.

Doull, J. L., Ayer, S.W., Singh, A. K. \& Thibault, P. (1993). Production of a novel polyketide antibiotic, jadomycin B, by Streptomyces venezuelae following heat shock. J Antibiot 46, 869-871.

Doull, J. L., Singh, A. K., Hoare, M. \& Ayer, S. W. (1994). Conditions for the production of jadomycin B by Streptomyces venezuelae ISP5230: effects of heat shock, ethanol treatment and phage infection. J Ind Microbiol 13, 120-125.

Eggink, G., Engel, H., Vriend, G., Terpstra, P. \& Witholt, B. (1990). Rubredoxin reductase of Pseudomonas oleovorans: structural relationship to other flavoprotein oxidoreductases based on one NAD and two FAD fingerprints. J Mol Biol 212, 135-142.

Fernandez-Moreno, M. A., Martinez, E., Caballero, L. J., Ichinose, K., Hopwood, D. A. \& Malpartida, F. (1994). DNA sequence and functions of the actVI region of the actinorhodin biosynthetic gene cluster of Streptomyces coelicolor A3(2). J Biol Chem 269, 24854-24863.

Han, L., Yang, K., Ramalingam, E., Mosher, R. H. \& Vining, L. C. (1994). Cloning and characterization of polyketide synthase genes for jadomycin B biosynthesis in Streptomyces venezuelae ISP5230. Microbiology 140, 3379-3389.

Haydock, S. F., Dowson, J. A., Dhillon, N., Roberts, G. A., Cortes, J. \& Leadlay, P. F. (1991). Cloning and sequence analysis of the genes involved in erythromycin biosynthesis in Saccharopolyspora erythraea. Sequence similarities between ery $G$ and a family of Sadenosylmethionine-dependent methyltransferases. Mol \& Gen Genet 230, 120-128.

Hong, Y.-S., Hwang, C. K., Hong, S.-K., Kim, Y. H. \& Lee, J. J. (1994). Molecular cloning and characterization of the aklavinone 11-hydroxylase gene of Streptomyces peucetius subsp. caesius ATCC 27952. J Bacteriol 176, 7096-7101.

Hopwood, D. A. \& Sherman, D. H. (1990). Molecular genetics of polyketides and its comparison to fatty acid biosynthesis. Annu Rev Genet 24, 37-66.

Hopwood, D. A., Bibb, M. J., Chater, K. F., Kieser, T., Bruton, C. J., Kieser, H. M., Lydiate, D. J., Smith, C. P. \& Schrempf, H. (1985). Genetic Manipulation of Streptomyces: a Laboratory Manual. Norwich: John Innes Foundation.

Hopwood, D. A., Chater, K. F. \& Bibb, M. J. (1994). Genetics of antibiotic production in Streptomyces coelicolor A3(2), a model streptomycete. In Genetics and Biochemistry of Antibiotic Production, pp. 65-102. Edited by L. C. Vining \& C. Stuttard. Newton, MA: Butterworth-Heinemann.

Hutchinson, C. R. (1994). Anthracyclines. In Genetics and Biochemistry of Antibiotic Production, pp. 331-357. Edited by L. C. Vining \& C. Stuttard. Newton, MA: Butterworth-Heinemann.

Imamura, N., Kakinuma, K., Ikekawa, N., Tanaka, H. \& Omura, S. (1982). Biosynthesis of vineomycins $\mathrm{A}_{1}$ and $\mathrm{B}_{2} . J$ Antibiot 35, 602-608.

Khosla, C., McDaniel, R., Ebert-Khosla, S., Torres, R., Sherman, D. H., Bibb, M. J. \& Hopwood, D. A. (1993). Genetic construction and functional analysis of hybrid polyketide synthases containing heterologous acyl carrier proteins. J Bacteriol 175, 2197-2204.

Kieser, T. (1984). Factors affecting the isolation of ccc DNA from Streptomyces lividans and Escherichia coli. Plasmid 12, 290-296.

Kim, E.-S., Hopwood, D. A. \& Sherman, D. H. (1994). Analysis of type II polyketide $\beta$-ketoacyl synthase specificity in Streptomyces coelicolor A3(2) by trans complementation of actinorhodin synthase mutants. J Bacteriol 176, 1801-1804.

Krohn, K. \& Khanbabaee, K. (1994). First total synthesis of ( \pm )rabelomycin. Angew Chem Int Ed Engl 33, 99-100.

Larson, J. L. \& Hershberger, C. L. (1986). The minimal replicon of a streptomycete plasmid produces an ultrahigh level of plasmid DNA. Plasmid 15, 199-209.

Liu, W.-C., Parker, W. L., Slusarchyk, D. S., Greenwood, D. L., Graham, S. F. \& Meyers, E. (1970). Isolation, characterization and structure of rabelomycin, a new antibiotic. $J$ Antibiot 23, 437-441.

McDaniel, R., Ebert-Khosla, S., Hopwood, D. A. \& Khosla, C. (1993). Engineered biosynthesis of novel polyketides. Science 262, 1546-1550.

MacNeil, D. J., Gewain, K. M., Rudy, C. L., Dezeny, G., Gibbons, P. H. \& MacNeil, T. (1992). Analysis of Streptomyces avermitilis genes required for avermectin biosynthesis utilizing a novel integration vector. Gene 111, 61-68.

Nebert, D. W. \& Gonzales, F. J. (1987). P450 genes: structure, evolution and regulation. Annu Rev Biocbem 56, 945-993.

Niemi, J. \& Mäntsălä, P. (1995). Nucleotide sequences and expression of genes from Streptomyces purpurascens that cause the production of new anthracyclines in Streptomyces galilaeus. J Bacteriol 177, 2942-2945.

Nurk, A., Kasak, L. \& Kivisaar, M. (1991). Sequence of the gene (phe A) encoding phenol monooxygenase from Pseudomonas sp. EST1001: expression in Escherichia coli and Pseudomonas putida. Gene 102, 13-18.

Omer, C. A., Lenstra, R., Litle, P. J., Dean, C., Tepperman, J. M., Leto, K. J., Romesser, J. A. \& O'Keefe, D. P. (1990). Genes for two herbicide-inducible cytochromes P-450 from Streptomyces griseolus. J Bacteriol 172, 3335-3345.

Orser, C. S., Lange, C. C., Xun, L., Zahrt, T. C. \& Schneider, B. J. (1993). Cloning, sequence analysis, and expression of the Flavo- 
bacterium pentachlorophenol-4-monooxygenase gene in Escherichia coli. J Bacteriol 175, 411-416.

Perkins, E. J., Gordon, M. P., Caceres, O. \& Lurquin, P. F. (1990). Organization and sequence analysis of the 2,4-dichlorophenol hydroxylase and dichlorocatechol oxidative operons of plasmid pJP4. J Bacteriol 172, 2351-2359.

Poulos, T. L., Finzel, B. C. \& Howard, A. J. (1987). High-resolution crystal structure of cytochrome $\mathrm{P}^{4} 0_{\mathrm{CAM}}$. J Mol Biol 195, 687-700.

Rohr, J. \& Thiericke, R. (1992). Angucycline group antibiotics. Nat Prod Rep 9, 103-137.

Rohr, J., Beale, J. M. \& Floss, H. G. (1989). Urdamycins, new angucycline antibiotics from Streptomyces fradiae. IV. Biosynthetic studies of urdamycins A-D. J Antibiot 42, 1151-1157.

Russel, M. \& Model, P. (1988). Sequence of thioredoxin reductase from Escherichia coli: relationship to other flavoprotein disulfide oxidoreductases. J Biol Chem 263, 9015-9019.

Sambrook, J., Fritsch, E. F. \& Maniatis, T. (1989). Molecular Cloning: a Laboratory Manual. Cold Spring Harbor, NY: Cold Spring Harbor Laboratory.

Sanger, F., Nicklen, S. \& Coulson, A. R. (1977). DNA sequencing with chain-terminating inhibitors. Proc Natl Acad Sci USA 74, 5463-5467.

Shen, B. \& Hutchinson, C. R. (1993a). Enzymatic synthesis of a bacterial polyketide from acetyl and malonyl coenzyme A. Science $262,1535-1540$

Shen, B. \& Hutchinson, C. R. (1993b). Tetracenomycin F2 cyclase: intramolecular aldol condensations in the biosynthesis of tetracenomycin C in Streptomyces glaucescens. Biochemistry 32, 11149-11154.

Sherman, D. H., Kim, E.-S., Bibb, M. J. \& Hopwood, D. A. (1992). Functional replacement of genes for individual polyketide synthase components in Streptomyces coelicolor A3(2) by heterologous genes from a different polyketide pathway. J Bacteriol 174, 6184-6190.
Southern, E. M. (1975). Detection of specific sequences among DNA fragments separated by gel electrophoresis. J Mol Biol 98, 503-517.

Stanzak, R., Matsushima, P., Baltz, R. H. \& Rao, R. N. (1986). Cloning and expression in Streptomyces lividans of clustered erythromycin biosynthesis genes from Streptomyces erythreus. Bio/Technology 4, 229-232.

Stassi, D., Donadio, S., Staver, M. J. \& Katz, L. (1993). Identification of a Saccharopolyspora erytbraea gene required for the final hydroxylation step in erythromycin biosynthesis. $J$ Bacteriol 175, 182-189

Stuttard, C. (1982). Temperate phages of Streptomyces venezuelae: lysogeny and host specificity shown by phages SV1 and SV2.J Gen Microbiol 128, 115-121.

Summers, R. G., Wendt-Pienkowski, E., Motamedi, H. \& Hutchinson, C. R. (1993). The tcm VI region of the tetracenomycin $\mathrm{C}$ biosynthetic gene cluster of Streptomyces glaucescens encodes the tetracenomycin $\mathrm{F} 1$ monooxygenase, tetracenomycin $\mathrm{F} 2$ cyclase and, most likely, a second cyclase. J Bacteriol 175, 7571-7580.

Weber, J. M., Leung, J. O., Swanson, S. J., Idler, K. B. \& McAlpine, J. B. (1991). An erythromycin derivative produced by targeted gene disruption in Saccharopolyspora erytbraea. Science 252, 114-116.

Wierenga, R. K., Terpstra, P. \& Hol, W. G. J. (1985). Interaction of pyrophosphate moieties with $\alpha$-helices in dinucleotide binding proteins. J Mol Biol 24, 1346-1357.

Wierenga, R. K., Terpstra, P. \& Hol, W. G. J. (1986). Prediction of the occurrence of the ADP-binding $\beta-\alpha-\beta$ fold in proteins using an amino acid fingerprint. J Mol Biol 187, 101-107.

Received 17 July 1995; revised 6 September 1995; accepted 13 September 1995. 